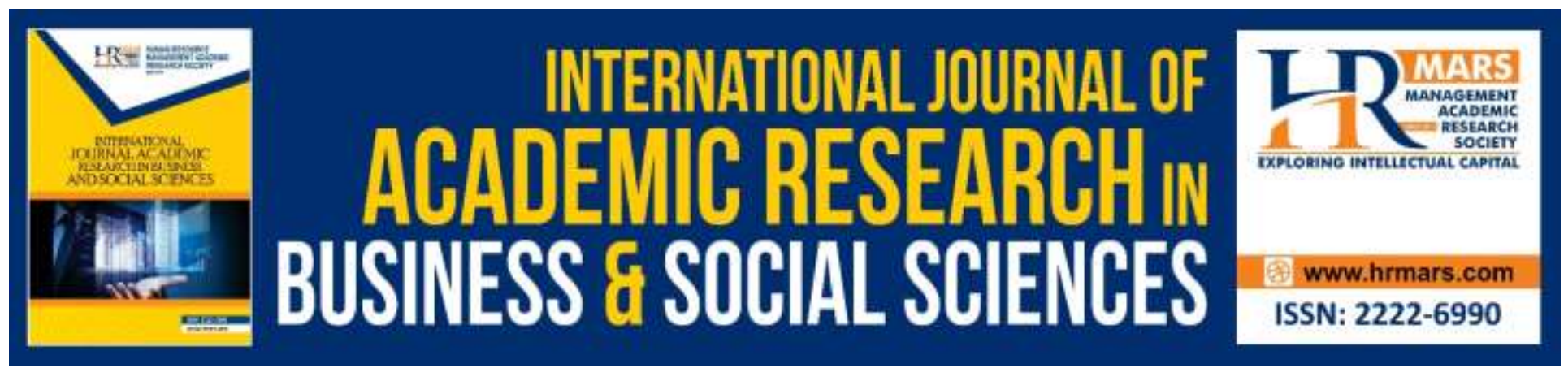

\title{
The Guideline for the User Interface Design of a Mobile Augmented Reality Learning Application for Children with Learning Difficulties
}

Nurhidayah Abdul Rahman, Ramlah Mailok, Nor Masharah Husain

To Link this Article: http://dx.doi.org/10.6007/IJARBSS/v10-i5/7168

DOI:10.6007/IJARBSS/v10-i5/7168

Received: 02 March 2020, Revised: 04 April 2020, Accepted: 26 April 2020

Published Online: 02 May 2020

In-Text Citation: (Rahman et al., 2020)

To Cite this Article: Rahman, N. A., Mailok, R., \& Husain, N. M. (2020). The Guideline for the User Interface Design of a Mobile Augmented Reality Learning Application for Children with Learning Difficulties. International Journal of Academic Research in Business and Social Sciences, 10(5), 13-22.

Copyright: (c) 2020 The Author(s)

Published by Human Resource Management Academic Research Society (www.hrmars.com)

This article is published under the Creative Commons Attribution (CC BY 4.0) license. Anyone may reproduce, distribute, translate and create derivative works of this article (for both commercial and non-commercial purposes), subject to full attribution to the original publication and authors. The full terms of this license may be seen

at: http://creativecommons.org/licences/by/4.0/legalcode

Vol. 10, No. 5, 2020, Pg. 13 - 22

http://hrmars.com/index.php/pages/detail/IJARBSS

JOURNAL HOMEPAGE

Full Terms \& Conditions of access and use can be found at http://hrmars.com/index.php/pages/detail/publication-ethics 


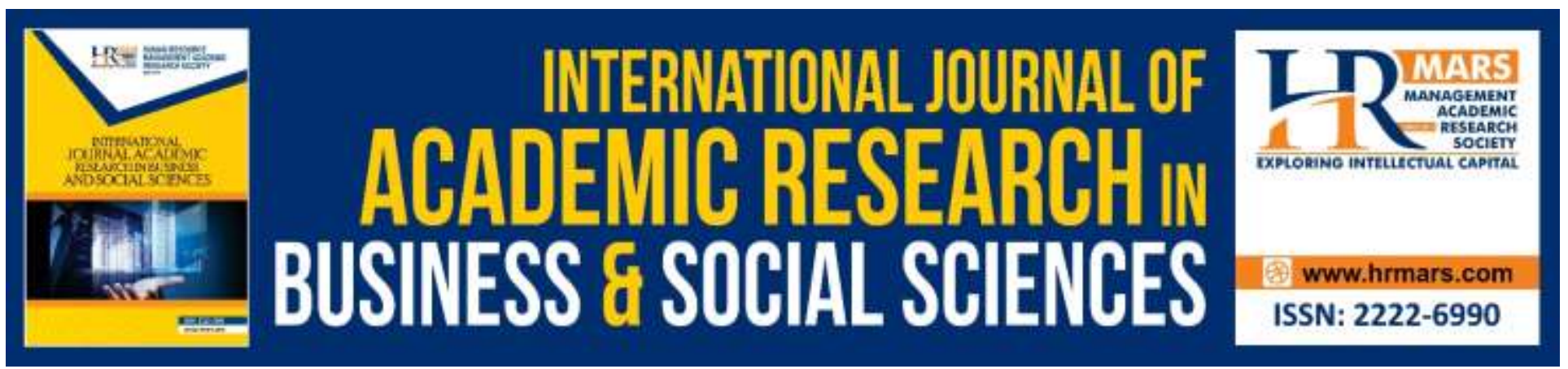

\title{
The Guideline for the User Interface Design of a Mobile Augmented Reality Learning Application for Children with Learning Difficulties
}

\author{
Nurhidayah Abdul Rahman, Ramlah Mailok, Nor Masharah Husain \\ Faculty of Art, Computing and Creative Industry (FSKIK), Sultan Idris Education University, 35900 \\ Tanjong Malim, Perak Darul Ridzuan, Malaysia. \\ Email: masharah.husain@gmail.com
}

\begin{abstract}
This study describes the guideline to build a user interface of a mobile Augmented Reality (AR) learning application, called BADANKU, for children with learning disabilities. Premised in this context, the researchers examined several guidelines for the design of user interfaces for users with disabilities, which have been reported in the current literature. Virtually, all guidelines reviewed have the same emphasis on the proper use of multimedia elements (notably texts, graphics, audios, and videos), fonts, icons, and their combinations that will have a profound impact on student learning. As such, the findings of this research will be used as the guideline for the researchers to develop the proposed user interface of a mobile AR learning application by focusing on relevant multimedia elements in a proper combination that can facilitate the learning process (which is dictated by the learning context) to ensure such children can read and understand information more efficaciously. Keywords: Augmented Reality, Children with Learning Difficulties, Mobile Applications, Multimedia Elements, User Interface Guidelines.
\end{abstract}

\section{Introduction}

Over recent years, the use of technologies to help children with learning difficulties has become intense. In particular, mobile technology has been widely used in teaching and learning activities involving such children. Such wide use is not surprising given that mobile devices, notably mobile phones and tablets, have become more affordable, allowing more and more people, including children, to own such devices. In today's educational landscape, students have been exposed to a wide spectrum of educational applications. As expected, they have become technologically savvy, making them eagerly passionate to learn in technology-enabled learning environments. A study by Mintz (2013) found that students preferred to learn using mobile phones compared to conventional learning carried by their teachers. Clearly, such a finding signifies students' proclivity for learning environments empowered by novel technologies. Of late, Augmented Reality (AR) technology has been making inroads in the educational realm, with many learning applications being developed 
based on such technology that offers highly interactive and immersive learning that can lead to improved learning performance.

a) The use of Augmented Reality (AR) technology and multimedia elements in the development of learning and training applications has intensified, signifying the many educational benefits to which both learners and educators can gain (Abdul Rahman et al., 2020).

b) Many researchers have been fascinated by such novel technology as evidenced by a plethora of studies focusing on its educational benefits. For example, Nincarean et al., (2013) conducted a study that found that the use of AR learning applications helped improve the quality of teaching through an interesting, appealing learning environment.

c) Interestingly, a study by Mustafa and Tuncel (2019), who reviewed the findings of previous findings, helped highlight the positive impact of such technology on students' learning performance, attitudes, and attention.

d) Teachers can leverage learning activities of students with learning disabilities with the use of mobile AR learning applications with multimedia elements, such as audio, graphics, animation, and video, the impact of which can make such students highly motivated, active, and interested in the learning process (Abdul Rahman et al., 2020).

e) As acknowledged, technology-enabled learning can have a huge impact on the learning efficacy of students, especially young children with learning disabilities (Abdul Rahman et al., 2020).

According to clinical experts, children with learning difficulties are those who have been identified and verified to have some forms of deformity that affects learning, which can be divided into several categories based on the level of their ability to function, such as cognitive ability, social behavior or social development, oral or speaking ability, reading ability, developmental skills, and mathematical ability (Hailmi, 2013). Children with special needs are typically those who have been diagnosed to have down syndrome, lack of intellectual ability, autism, attention deficit hyperactivity disorder (ADHD), and specific learning difficulties (Kementerian Pendidikan Malaysia, 2019). Previously, such students were inappropriately called mentally-challenged or mongoloid or other demeaning terms. Now, with greater empathy, they are referred to as children with learning difficulties or children with special needs (Salim, 2015).

In general, children with learning difficulties will have problems to read, write, and make simple calculations, with some of such students having to struggle even when they have reached the ages of five and six (Salim, 2015). Given such a predicament, the provision of guidelines to facilitate these students to read and understand information must be emphasized. In this regard, as highlighted by Freyhoff et al., (1998), 'easy to read' is one of the methods to help such children to gain access to information and make sense of it. Essentially, information that is easy to read must have the following traits:
a) Highly accessible.
b) Highly discernable.
c) Simple (with the use of words and pictures). 
Admittedly, the abilities and needs of such children vary significantly. Inevitably, some students, especially those who unable to read, will face great difficulties in understanding information that they have gained access to. To mitigate such a problem, audio narration can be used as an appropriate method to help such students (Freyhoff et al., 1998). To date, many initiatives have been proposed and carried out to help physically challenged people to efficiently access information from several communication platforms. For example, through the Web Accessibility Initiative (WAI), a user interface based on the guidelines prescribed by Forth from the World Wide Web Consortium (W3C) was proposed to help such a group of users based on the 'inclusive design'. The purpose of this initiative was to improve the effectiveness and usability of devices that could help promote smooth interaction between different components of the web technology, such as contents, web browsers, assistive technologies, users, developers, authoring tools, and assessment tools.

\section{Literature Review}

Through the critical review of previous studies, the researchers were able to identify relevant guidelines of user interface that were deemed appropriate for students with learning difficulties, which are summarized in Table 1.0.

Table 1.0

Guidelines of user interface design

\begin{tabular}{|c|c|}
\hline Author/Year & Guideline \\
\hline $\begin{array}{l}\text { 1. Freyhoff et al. } \\
(1998)\end{array}$ & $\begin{array}{l}\text { i. Avoid using pictures as background as they can make reading texts } \\
\text { difficult. } \\
\text { ii. Avoid putting too much information on a user interface. If texts } \\
\text { can give new information, consider using a new page instead. } \\
\text { iii. Use not more than two types of fonts, with the first for the title } \\
\text { and the other for texts. } \\
\text { iv. Use clear, readable fonts, such as Arial, Helvetica, and Times } \\
\text { New Roman. } \\
\text { v. Choose appropriate font sizes, preferably the size of } 14 \text { points that } \\
\text { is suitable for users with impaired vision. } \\
\text { vi. Exercise caution when using texts for emphasis. Avoid using italic } \\
\text { for emphasis; instead, use bold or underline. } \\
\text { vii. Ensure illustrations are in sharp focus and examine the quality of } \\
\text { printed pictures. } \\
\text { viii. Combine texts and audio to facilitate understanding and feedback } \\
\text { and to make information easily accessible. } \\
\text { ix. Use videos as an effective means to convey information to } \\
\text { students with learning difficulties. } \\
\text { x. Combine visual and verbal information to help users who have } \\
\text { difficulties to read texts. } \\
\text { xi. Ensure videos are clear and appropriately paced. }\end{array}$ \\
\hline
\end{tabular}




\begin{tabular}{|c|c|c|}
\hline $\begin{array}{l}\text { 2. Department of } \\
\text { Health UK } \\
(2009)\end{array}$ & $\begin{array}{l}\text { i. } \\
\text { ii. } \\
\text { iii. } \\
\text { iv. } \\
\text { v. } \\
\text { vi. } \\
\text { vii. } \\
\text { viii. } \\
\text { ix. } \\
\text { x. } \\
\text { xi. } \\
\text { xii. } \\
\text { xiii. } \\
\text { xiv. }\end{array}$ & $\begin{array}{l}\text { Rule 1: Every idea may require texts and pictures. } \\
\text { Rule 2: Juxtaposing texts and pictures helps users to understand } \\
\text { information. } \\
\text { Rule 3: Identify pictures that support texts. } \\
\text { Rule 4: Pictures should be made easily identifiable, } \\
\text { Rule 5: Pictures should be positioned to the left. } \\
\text { Rule 6: Pictures can be either drawings or images or graphics. } \\
\text { Rule 7: Pictures should be as large as possible. } \\
\text { Rule 8: Texts need to be easily understood. } \\
\text { Rule 9: If unfamiliar texts are to be used, inform users of their } \\
\text { meanings. } \\
\text { Rule 10: Place texts on the right side. } \\
\text { Rule 11: Texts must be written legibly by using appropriate fonts, } \\
\text { notably Arial. } \\
\text { Rule 12: Texts must be reasonably large by using a font size of } 14 \\
\text { or more. } \\
\text { Rule 13: Every sentence should be short by having not more than } \\
15 \text { words; otherwise, reading and understanding such a sentence } \\
\text { will be difficult. } \\
\text { Rule 14: Every document must be short by having not more than } \\
20 \text { pages. }\end{array}$ \\
\hline 3.Pavlov (2014) & $\begin{array}{l}\text { i. } \\
\text { ii. } \\
\text { iii. } \\
\text { iv. } \\
\text { v. } \\
\text { vi. } \\
\text { vii. } \\
\text { viii. } \\
\text { ix. } \\
\text { x. } \\
\text { xi. }\end{array}$ & $\begin{array}{l}\text { Use good contrast between a font and a background. } \\
\text { Use light colors or moderately bright colors. } \\
\text { Separate text boxes from other texts. } \\
\text { Place texts in a single column. } \\
\text { Use clear fonts, such as sans-serif. } \\
\text { Use simple graphics. } \\
\text { Do not use bright colors against texts. } \\
\text { Do not use images against a background. } \\
\text { Do not use overlapping images and transparent texts. } \\
\text { Do not use too many colored icons. } \\
\text { Do not use buttons with icons, except for common actions, such } \\
\text { as "Back". }\end{array}$ \\
\hline $\begin{array}{l}\text { 4. Gossen, Nitsche, \& } \\
\text { Nürnberger } \\
\text { (2012) }\end{array}$ & i. & $\begin{array}{l}\text { Images supported with audio narration can help students with } \\
\text { reading impediment. }\end{array}$ \\
\hline 5. Brooks (2012) & & $\begin{array}{l}\text { To maximize readability and understanding, large fonts, such as } \\
\text { Serif and Arial fonts, should be used. } \\
\text { Studies have shown that instructions can be clearer when texts } \\
\text { are accompanied by audio. Effectively, audio helps improve the } \\
\text { understanding of a particular piece of information. } \\
\text { dren can learn more effectively using learning materials with } \\
\text { three-dimensional animated objects. }\end{array}$ \\
\hline
\end{tabular}




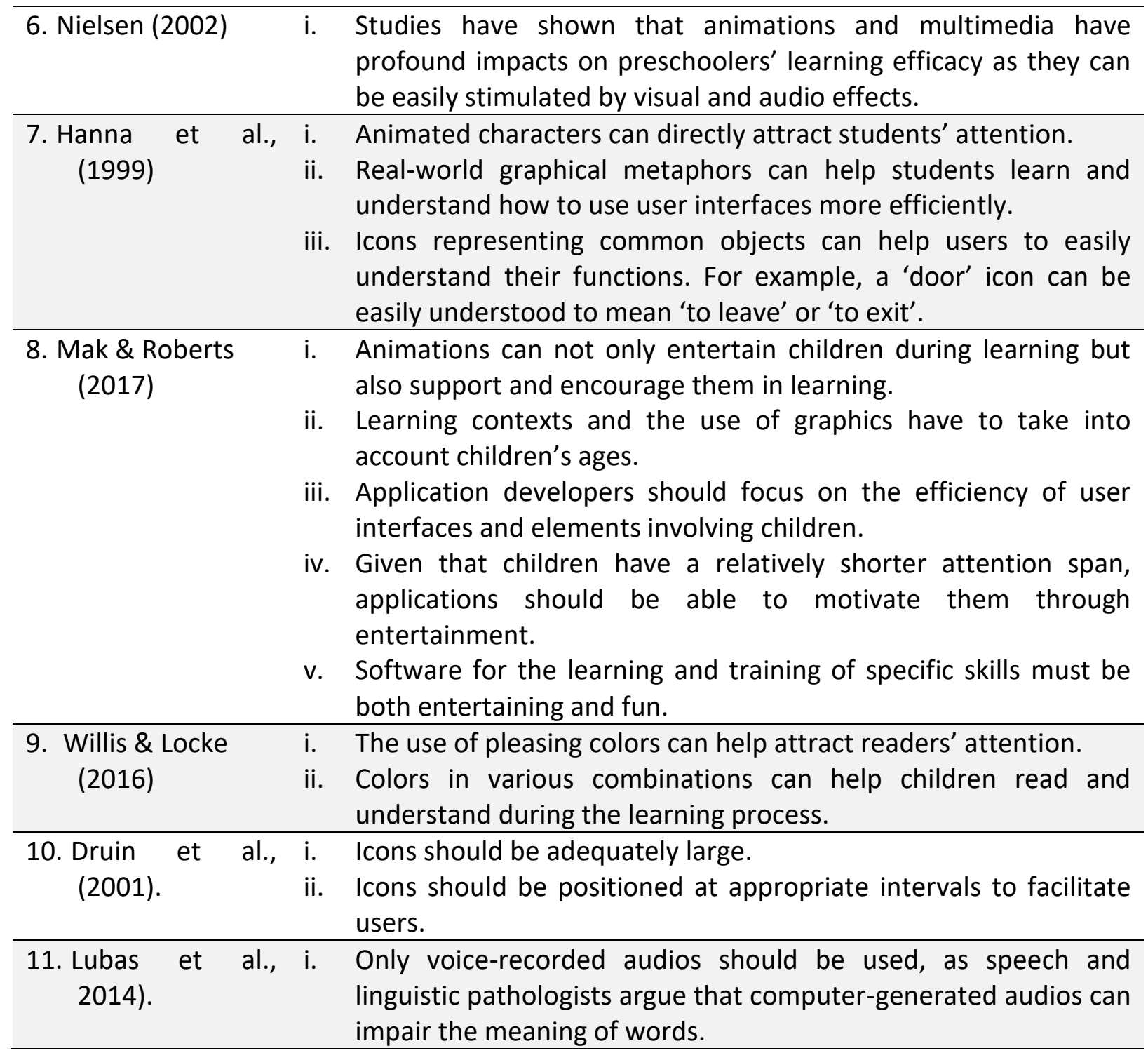

Certainty, appropriate guidelines are needed to help physically challenged users to gain access to desired information more easily. To date, several guidelines have been proposed by several researchers. For example, Freyhoff et al. (1998) proposed the European Guidelines to help users with physical disabilities. Likewise, the Department of Health, UK (2009) proposed a guideline to help physically challenged users to create documents of texts. Surprisingly, this guideline (despite being used for textual documents) has been effectively used in the design of user interfaces for children with disabilities. Its effectiveness has been validated by Pavlov (2014) based on studies by Khowaja and Salim (2013) and Lin et al., (2013). Table 2.0 summarizes the findings of studies of the design of user interfaces for children with disabilities. 
INTERNATIONAL JOURNAL OF ACADEMIC RESEARCH IN BUSINESS AND SOCIAL SCIENCES

Vol. 10, No. 5, May, 2020, E-ISSN: 2222-6990 @ 2020 HRMARS

Table 2.0

The findings of studies of the design of user interfaces for children with disabilities

Element

Guideline

1. Texts

2. Graphics/Images

i. Use good quality pictures.

ii. Use a combination of visual and verbal elements that can be easily understood.

iii. Pictures have to be placed adjacent to texts.

iv. Use pictures that can be easily understood.

v. Pictures have to be as large as possible.

vi. Pictures have to be placed on the left-hand side.

vii. Contexts and graphics have to be relevant to children's ages.

viii. Real-world graphical metaphors can help users to understand user interfaces.

3. Audios

i. In addition to texts, the use of audios can enhance understanding.

ii. Only use voice-recorded audios (as speech and linguistic pathologists warn that computer-generated audios can impair the meaning of words).

4. Videos

i. In addition to texts, the use of videos can enhance understanding.

ii. The combination of texts and videos can help children with learning difficulties in understanding user interfaces.

i. Videos have to be clear.

ii. Videos have to be played with the correct speed.

5. Animations

i. Animations can help improve understanding. 


ii. $\begin{aligned} & \text { Good animation effects can have a positive impact on } \\
& \text { preschoolers with learning difficulties because visual and audio } \\
& \text { can stimulate their senses. }\end{aligned}$
\begin{tabular}{ll} 
iii. Animated characters can directly attract students' attention. \\
\hline 6. Icons
\end{tabular}
$\begin{array}{ll}\text { ii. Icons should be preferably large. } \\
\text { iii. Icons should be placed at appropriate distances with one another } \\
\text { to help users. }\end{array}$
iv. Avoid using multi-colored icons.
v. Avoid using buttons with icons, except for general, intuitive
commands, such as "BACK".
i. Colors project attractive images that users find interesting to
ii. Use light and moderately bright colors.
iii. Avoid using highly bright colors.

Table 2.0 shows some of the guidelines for the design of user interface for children with disabilities based on previous studies. Clearly, all the above guidelines focus on the importance of multimedia elements, such as texts, graphics, audios, videos, animations, icons, and colors, in developing suitable user interfaces for such children. In particular, a good combination of texts and pictures is needed to help children with learning difficulties to gain access to and make sense of information. In this respect, Pavlov (2014) asserts that certain multimedia elements can be used to replace texts that students, notably children with learning difficulties, find difficult to read. Such assertion clearly underscores the importance of multimedia elements to help such children in learning. In addition, according to Carbo (1995) (cited in Willis and Lockee, (2016), various combinations of colors can help students to read and understand texts regarding a subject matter more effectively.

Such a notion concurs with the findings of a study by Belfiore et al., (1996), which show colors can significantly improve learning performances of students with learning difficulties. Emerging findings of new studies have further reinforced the importance of colors for student learning. For example, a study on mobile applications for Malaysian dyscalculia children by Ariffin et al., (2017) found that white, beige, and soft pink pastel were very effective when used as background colors to help stimulate students' minds to stay focused in learning. In contrast, they found that the use of bright colors would produce the opposite effect.

\section{Conclusion}

As revealed in this study, several guidelines for the design of user interfaces for children with learning difficulties have been proposed by a number of researchers. These guidelines provide important insights into the proper use of multimedia elements (notably texts, graphics, audios, and videos), fonts, icons, and their combinations that will have a profound impact on student learning. As such, the findings of this research will be used as the guideline for the researchers to develop the proposed user interface of a mobile AR learning application by focusing on relevant multimedia elements in a 
INTERNATIONAL JOURNAL OF ACADEMIC RESEARCH IN BUSINESS AND SOCIAL SCIENCES

Vol. 10, No. 5, May, 2020, E-ISSN: 2222-6990 @ 2020 HRMARS

proper combination that can facilitate the learning process (which is dictated by the learning context) to ensure such children can read and understand information more efficaciously.

\section{References}

Belfiore, P. J., Grskovic, J. A., Murphy, A. M., \& Zentall, S. S. (1996). The Effects of Antecedent Color on Reading for Students with Learning Disabilities and Co-Occurring AttentionDeficit/Hyperactivity Disorder. Journal of Learning Disabilities, 29(4), 432-438.

Brooks, M. (2012). Best Practices: Designing Touch Tablet Experiences for Pre-schoolers. Retrieved from http://www.sesameworkshop.org/wp_install/wpcontent/uploads/2013/04/BestPractices-Document- 11-2612.pdf

Carbo, M. (1995). National Reading Styles Institute Brochure. Retrieved from https://www.nrsi.com/catalogs.php

Department of Health, UK. (2009). Basic Guidelines for People Who Commission Easy Read Information. Department of Health, United Kingdom.

Druin, A., Bederson, B. B., Hourcade, J. P., Sherman, L., Revelle, G., Platner, M., \& Weng, S. (2001). Designing a digital library for young children: An Intergeneration Partnership. Proceedings of the 1st ACM/EEE-CS joint conference on Digital libraries (pp.398-405). ACM. https://doi.org/10.1016/B978-155860915-0/50038-8

Freyhoff, G., Hess, G., Kerr, L., Tronbacke, B., \& Veken, V. D. K. (1998). Make it simple: European guidelines for the production of easy-to-read information for people with learning disability for authors, editors, information providers, translators and other interested persons. ILSMH European Association.

Geist, E. (2014). Using tablet computers with toddlers and young preschoolers. Young Children, 69(1), 58. Retrieve from https://cpb-us-

w2.wpmucdn.com/sites.gsu.edu/dist/8/428/files/2014/08/Using-Tablet- Computers -withToddlers-and-Young-Preschoolers-12aq5gs.pdf

Gossen, T., Nitsche, M., \& Nürnberger, A. (2012). Search User Interface Design for Children: Challenges and Solutions. In EuroHCIR. 59-62.

Hanna, L., Risden, K., Czerwinski, M., \& Alexander, K. J. (1999). The role of usability research in designing children's computer products. The design of children's technology, 3-26.

Hayes, G. R., Hirano, S., Marcu, G., Monibi, M., Nguyen, D. H., \& Yeganyan, M. (2010). Interactive visual supports for children with autism. Personal and Ubiquitous Computing, 14(7), 663680.

Khowaja, K., \& Salim, S. S. (2013). A Systematic Review of Strategies and Computer-Based Intervention (CBI) for Reading Comprehension of Children with Autism. Research in Autism Spectrum Disorders. 7(9), 1111-1121.

Kementerian Pendidikan Malaysia. (2019). Pentafsiran Bilik darjah (PBD) murid Berkeperluan Khas (MPK) Masalah Pembelajaran Tahap 1. KPM, Malaysia.

Lin, C. S., Chang, S. H., Liou, W. Y., \& Tsai, Y. S. (2013). The Development of a Multimedia Online Language Assessment Tool for Young Children with Autism. Research in Development Disabilities. 24(10). 3553-3565. https://doi.org/10/1016/j.ridd.2013.06.042

Lubas, M., Mitchell, J., \& De Leo, G. (2014). User-Centered Design and Augmentative and Alternative Communication Apps for Children with Autism Spectrum Disorders. SAGE Open. https://doi.org/ 10.1177/2158244014537501 
INTERNATIONAL JOURNAL OF ACADEMIC RESEARCH IN BUSINESS AND SOCIAL SCIENCES

Vol. 10, No. 5, May, 2020, E-ISSN: 2222-6990 @ 2020 HRMARS

Mak, D., \& Roberts, D. (2017). Design Considerations for Educational Mobile Apps for Young Children. Proceedings of the Human Factors and Ergonomics Society Annual Meeting, 61(1), 1156-1160. https://doi.org/10.1177/1541931213601773

Ariffin, M., Abd Halim, F. A., \& Abd Aziz, N. (2017). Mobile application for dyscalculia children in Malaysia in Zulikha, J. \& N. H. Zakaria (Eds.). Proceedings of the $6^{\text {th }}$ International Conference on Computing \& Informatics (pp 467-472). Sintok, Malaysia.

Mintz, J. (2013). Additional key factors mediating the use of a mobile technology tool designed to develop social and life skills in children with Autism Spectrum Disorders: Evaluation of the 2nd HANDS prototype. Computers \& Education. 63, 17-27.

http://dx.doi.org/10.1016/j.compedu.2012.11.006

Mustafa, F., \& Tuncel, M. (2019). Integrating augmented reality into problem-based learning: The effects on learning achievement and attitude in physics education. Computers \& Education, 103635. http://doi:10.1016/j.compedu.2019.103635

Nincarean, D., Alia, M., Halim, N., \& Rahman, M. (2013). Mobile Augmented Reality: The Potential for Education. Procedia - Social and Behavioral Sciences, 103, 657-664. https://doi.org/10.1016/j.sbspro.2013.10.385

Nielsen, J. (2002). Kids' corner: Website usability for children. Jakob Nielsen's Alertbox. Retrieve from http://district4.extension.ifas.ufl.edu/Tech/TechPubs/Usability4Children.pdf

Abdul Rahman, N., Mailok, R., \& Husain, N. M. (2020). Mobile Augmented Reality Learning Application for Students with Learning Disabilities. International Journal of Academic Research in Business and Social Sciences, 10(2), 133-141. http://dx.doi.org/10.6007/IJARBSS/v10-i2/6896

Pavlov (2014). User Interface for People with Autism Spectrum Disorders. Journal of Software Engineering and Applications, 2014, 7, 128-134. http://dx.doi.org/10.4236/jsea.2014.72014

Salim, R. (2015). Pengurusan Pendidikan Khas: Masalah Pembelajaran. Dewan Bahasa dan Pustaka, Kuala Lumpur. Attin Press Sdn Bhd.

Willis, L., \& Lockee, B. (2008). Examining the Use of Colored Overlays with Field Dependent, Reading Disabled Children. Journal of Visual Literacy. 27, 155-178. https://doi.org/D10.1080/23796529.2008.11674654. 